\title{
Oxygen consumption in the sandy beaches of the Vistula River: Goods and services of the ecosystem ${ }^{*}$
}

\section{Zużycie tlenu przez plażę wiślaną. Dobra i usługi ekosystemu}

\author{
Patrycja Słodownik, Krzysztof W. Opaliński \\ Institute of Ecology and Bioethics, Cardinal Stefan Wyszyński University in Warsaw, Poland \\ ORCID: KWO https://orcid.org/0000-0002-9653-3383•k.opalinski@uksw.edu.pl
}

\begin{abstract}
The research aimed to estimate the role of the beach in the process of self-purification of water in the Vistula River. The study could become a very important voice in the debate about the future of the Vistula River. A self-purification process involves the disposal of pollutants entering the water from the catchment of the river. A measure of the Vistula River water purification process of organic matter is the amount of oxygen that is consumed by the beach settlement. That is the amount of utilised organic matter by psammon during cellular respiration. Besides, the calculation of the amount of organic matter, which was worn by psammon can be the measure of "goods and services of the ecosystem" of the river.
\end{abstract}

Keywords: Vistula River, self-purification, psammon, oxygen consumption, goods and services of the ecosystem

Streszczenie: Celem pracy jest ocena roli piaszczystych plaż w procesie samooczyszczania wód Wisły. Wyniki tej pracy mogą być ważnym głosem w dyskusji o przyszłości Wisły. Proces samooczyszczania polega na usuwaniu zanieczyszczeń wprowadzanych do wody również ze zlewni rzeki. Miarą procesu oczyszczania wody w Wiśle z materii organicznej jest ilość tlenu zużywanego przez piaszczyste plaże w procesach utylizowania tej materii przez psammon podczas oddychania komórkowego. Ilość materii organicznej, która jest utylizowana przez psammon jest miarą "dóbri usług ekosystemu" rzeki.

Słowa kluczowe: Wisła, samooczyszczenie, psammon, zużycie tlenu, dobra i usługi ekosystemu

\section{Introduction \\ Psammon - the interstitial organism of the beaches}

Psammon is a group of organisms inhabiting wet coastal sand, the interstitial spaces between grains of sand. It consists mainly of bacteria, algae, protozoan, rotifers, gastrotrichs, nematodes, annelids, tardigrades and copepods. Their living environment is water located between grains of sand, usually strongly saturated with mineral salts and organic compounds (Wiszniewski 1934).

Interstitial organisms feed on dissolved and particulate organic matter carried by water, which is infiltrated by sandbanks and beaches. This organic matter is then used for the construction of their bodies and energy processes (cellular respiration) (Kleiber 1961; Klekowski, and Duncan 1975; Klekowski, and Opaliński 1993). The discoverer of the psammon community and the author of this term is Polish zoologist and hydrobiologist Jerzy Wiszniewski,

" This article was originally published in Polish as Słodownik, Patrycja, i Krzysztof W. Opaliński. 2015. "Zużycie tlenu przez plażę wiślaną. Dobra i usługi ekosystemu." Studia Ecologiae et Bioethicae 13(4): 179-194. The translation of the article into English was financed by the Ministry of Science and Higher Education of the Republic of Poland as part of the activities promoting science - Decision No. 676/P-DUN/2019 of 2 April 2019. Translation made by GROY Translations. 
who worked in Research Station on Wigry Lake in 1930-1935 and organized Research Station in Pińsk (Wiszniewski 1934, 1947).

The amount of oxygen consumed in the respiratory processes of the organisms indicates the amount of organic matter taken from the environment and used for energy processes and thus the amount of decomposed organic matter (see Kleiber 1961). The same process occurs in interstitial water of sandbanks: the organic matter carried by the water is biologically utilised by psammon (Puczko 2013). Knowing the amount of oxygen consumed by the sand, it is possible to calculate how much organic matter carried by the water is consumed and thus to assess the role played by the sandbanks, sandy beaches and inhabiting it psammon in self-purification of riverine water.

\section{Aim of the research}

This research aims to estimate the role of the beach in the process of self-purification of water in the Vistula River. A measure of the Vistula water purification process of organic matter, mainly from municipal sewage, is the amount of oxygen that is consumed by the sandy beach, i.e. the amount of utilised organic matter by psammon during cellular respiration.

The assessment of the amount of organic matter utilised by psammon inhabiting beaches, sandbanks and other Vistula River sand formations, apart from a purely cognitive purpose (this type of research on river beaches was so far conducted by Puczko (2013)), also has a practical aspect. Namely, it can facilitate "evaluation" of Goods and Services of the Ecosystem sensu Constanza 1999; Constanza et al. 1997 and it will be an important voice in the debate about the future of the Vistula River. Will the "Queen of Polish Rivers" become "the last great wild river of Europe" or be turned into a storm drain and a waterway.

\section{Study area and methods 1.1. Study area}

The research was conducted on the central part of the Vistula River in Warsaw, on the right, sandy and non-regulated side of the river, next to Śląsko-Dąbrowski bridge, near the La Playa club. It is a sandy beach, or according to Kajak's nomenclature (Kajak 1998) - psammolittoral zone.

\subsection{Methods}

The research method used in this study is the method of closed vessels (Lampert 1984). Of many other methods, this one proved to be the best as it allows synchronous measurements of many samples.

To calculate the total, biotic and abiotic oxygen consumption by the beach one has to measure the total and abiotic oxygen consumption and, based on this measurement, calculate the biotic consumption in a riverine water. Erlenmayer flasks with a capacity of $0.120 \mathrm{dm}^{3}$ were used for measuring. After filling the flasks with water, the oxygen content in water closed in flasks was measured. Next, the flasks were exposed to Vistula water for 24 hours. To measure the content of oxygen in the flasks, a Hach-Lange oxygen probe was used. The probe is equipped with an HQ40D digital meter and an LDO luminescent electrode (luminophore LED). Luminescent electrode uses an optical measurement of oxygen dissolved in water. The decrease in oxygen content in the studied flasks was treated as total oxygen consumption.

For the calculation of biotic and abiotic oxygen consumption in water, the method of adding formaldehyde to the sample was used (Urban-Malinga, and Opaliński 1999). For this purpose, five samples of water were taken, to which $2 \mathrm{~cm}^{3}$ of concentrated formaldehyde was added. Next, the flasks were put in a dark place. Formaldehyde kills organisms living in water, so the reduction of oxygen in the flask is caused by the chemical processes occurring in the water. It is called abiotic oxygen consumption. Biotic oxygen consumption means the difference between total oxygen consumption and abiotic oxygen consumption. Biotic oxygen consumption is associated with the life processes of plankton organisms living in a water column. 
For measuring the total, biotic and abiotic oxygen consumption in the sand, the closed vessel method was also used. Samples from beach sand were taken using $1.33 \mathrm{~cm}^{2}$ glass probe. The sample area was $1.33 \mathrm{~cm}^{2}$ and thickness was $10 \mathrm{~cm}$. Samples were placed in Erlenmeyer flasks with a capacity of $0.120 \mathrm{dcm}^{3}$ and filed up with riverine water. Oxygen content was measured in each flask. Next, five flasks were closed. To each of the other five flasks, $2 \mathrm{~cm}^{3}$ of formaldehyde was added, and then flasks were closed and put in a dark place. All flasks were exposed to 24 hours. After this time, the oxygen content in all flasks was measured again.

The loss of oxygen in flasks without formaldehyde (Total Oxygen Consumption) was caused by oxygen consumption by psammon, which lives in sand, and plankton living in the water, and abiotic processes in water and sand. The loss of oxygen in flasks with formaldehyde was caused by abiotic processes (Abiotic Oxygen Consumption). If to subtract the Abiotic Oxygen Consumption in a flask from the obtained value of the Total Oxygen Consumption, Biotic Oxygen Consumption in the sample of water and sand is obtained.
If oxygen consumption in flasks with water is subtracted from oxygen consumption in flasks with water and sand, oxygen consumption by the sand probe is obtained. The calculation of oxygen consumption per unit of sand sample surface $\left(\mathrm{m}^{2}\right)$ is possible by including the capacity of Erlenmeyer flasks.

In this study, the measurements of oxygen consumption, made every month from 2009 to 2013, were presented. In the 2009-2010 period, the measurements were made by $\mathrm{dr}$ Magdalena Puczko (Puczko 2013), in 2011 by prof. Krzysztof Opaliński (unpublished data), in 2012 by Anna Kozieł (Kozieł 2013) and Marlena Ludwiniak (Ludwiniak 2013). The measurements in the second part of 2012 and 2013 were made by the authors.

\section{Results}

\subsection{Total oxygen consumption by the Vistula River beach in years 2009-2013}

Total oxygen consumption by the Vistula beach (Fig. 1) has reached its highest value in 2012. The highest total oxygen consumption $\left(1.72 \mathrm{gO}_{2} \mathrm{~m}^{-2} \mathrm{~d}^{-1}\right)$ was observed in September 2012. High total consumption was also evident in August 2012 (1.60 $\left.\mathrm{gO}_{2} \mathrm{~m}^{-2} \mathrm{~d}^{-1}\right)$, July $2012\left(1.34 \mathrm{gO}_{2} \mathrm{~m}^{-2} \mathrm{~d}^{-1}\right)$,

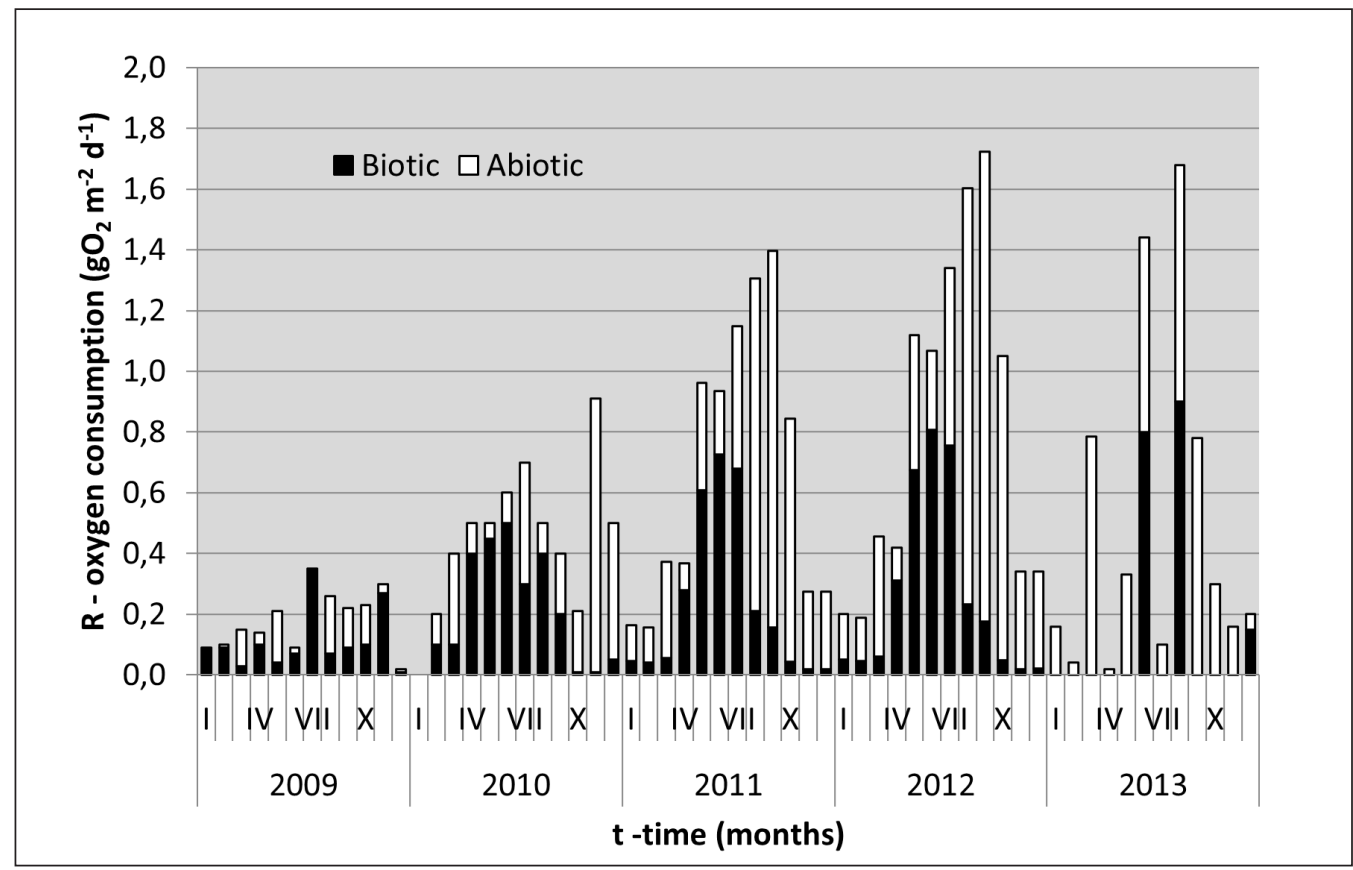

Fig. 1. Biotic and abiotic oxygen consumption by the Vistula beach in the years 20092013. Total oxygen consumption is the sum of biotic and abiotic consumption. 


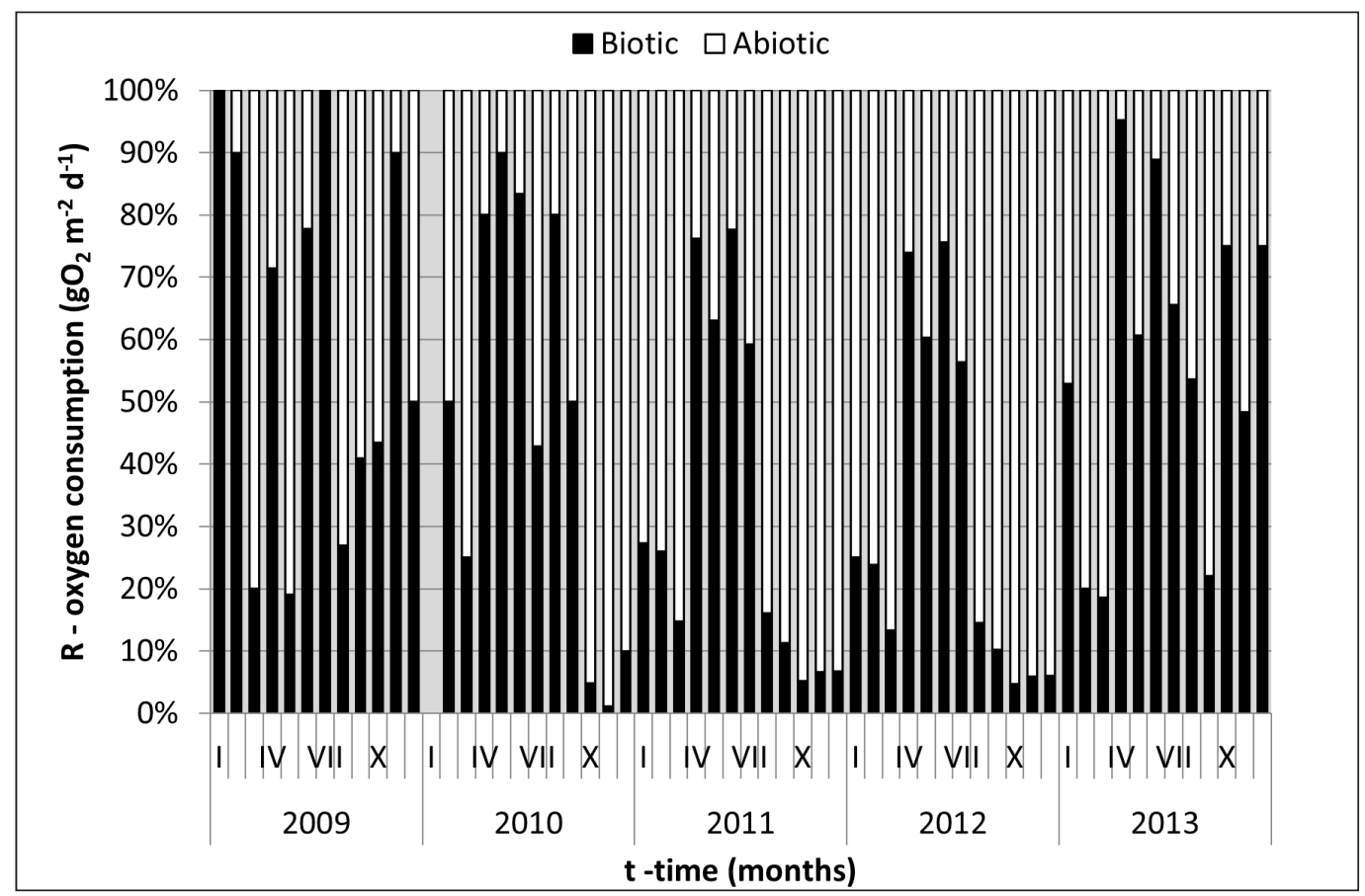

Fig. 2. The percentage of biotic oxygen consumption in the total oxygen consumption by the Vistula River beach in the years 2009-2013. The multi-annual average of biotic oxygen consumption is $52.3 \%$ of the total oxygen consumption.

May $2012\left(1.12 \mathrm{gO}_{2} \mathrm{~m}^{-2} \mathrm{~d}^{-1}\right)$ and June 2012 $\left(1.07 \mathrm{gO}_{2} \mathrm{~m}^{-2} \mathrm{~d}^{-1}\right)$. The lowest values of total oxygen consumption were observed in winter, from December to March. The zero value occurred in February 2010. In January 2009 and 2011, the value of total oxygen consumption was only $0.1 \mathrm{gO}_{2} \mathrm{~m}^{-2}$ $\mathrm{d}^{-1}$. In January 2012 and 2013 total oxygen consumption by the beach was higher than in previous years - in January 2012: $0.20 \mathrm{gO}_{2} \mathrm{~m}^{-2} \mathrm{~d}^{-1}$, and in January 2013: 0.30 $\mathrm{gO}_{2} \mathrm{~m}^{-2} \mathrm{~d}^{-1}$. The value of total oxygen consumption of the beach has been increasing gradually since the beginning of the year, reaching its maximum in July, August and September, and then gradually decreasing. The year 2010 had the lowest average annual total oxygen consumption, while the year 2012 had the highest.

\subsection{Biotic oxygen consumption by the beach}

Biotic oxygen consumption by the Vistula River beach (Fig. 1) has reached its highest value in June $2012\left(0.81 \mathrm{gO}_{2} \mathrm{~m}^{-2} \mathrm{~d}^{-1}\right)$. The year
2012 was characterized by very high values of biotic oxygen consumption by the Vistula River beach: in August it reached $0.76 \mathrm{gO}_{2}$ $\mathrm{m}^{-2} \mathrm{~d}^{-1}$, in June - $0.67 \mathrm{gO}_{2} \mathrm{~m}^{-2} \mathrm{~d}^{-1}$, in April $0.31 \mathrm{gO}_{2} \mathrm{~m}^{-2} \mathrm{~d}^{-1}$. The lowest values were recorded during winter. In February 2010 biotic oxygen consumption fell to zero, minimal values: $0.01 \mathrm{gO}_{2} \mathrm{~m}^{-2} \mathrm{~d}^{-1}$ were recorded in October 2010, November 2009, 2010, in January 2009, 2010, 2011, 2013, in February 2011, 2013, and in March 2010. It is worth noting that starting with winter (November) 2011, the value of biotic oxygen consumption was increasing until July 2012. The highest value of biotic oxygen consumption in 2009 was in August and it was $0.25 \mathrm{gO}_{2} \mathrm{~m}^{-2} \mathrm{~d}^{-1}$, in 2010 in April and August - $0.04 \mathrm{gO}_{2} \mathrm{~m}^{-2} \mathrm{~d}^{-1}$, in 2011 in June $-0.19 \mathrm{gO}_{2} \mathrm{~m}^{-2} \mathrm{~d}^{-1}$. The year 2010 was characterized by the lowest average biotic oxygen consumption by the beach.

\subsection{Abiotic oxygen consumption by the beach}

Abiotic oxygen consumption by the beach (Fig. 1) has reached its highest val- 
ue in September $2012-1.55 \mathrm{gO}_{2} \mathrm{~m}^{-2} \mathrm{~d}^{-1}$. High values also appeared in August 2012 - $1.37 \mathrm{gO}_{2} \mathrm{~m}^{-2} \mathrm{~d}^{-1}$, October $2012-1.00 \mathrm{gO}_{2}$ $\mathrm{m}^{2} \mathrm{~d}^{-1}$. Considering the period between 2009-2013, in 2012 there was the highest average the abiotic oxygen consumption by the Vistula River beach. Between October and March, the abiotic oxygen consumption reached its lowest values. Zero values were recorded in January 2009, 2010 and in February 2010. Also, the low value of $0.01 \mathrm{gO}_{2} \mathrm{~m}^{-2} \mathrm{~d}^{-1}$ was reported in December 2010, in February 2009 and 2011, in March 2009, 2010 and 2011, in April 2010, August 2010 and 2011, in September 2010 and 2011. The year 2010 is characterized by the lowest average value of the abiotic oxygen consumption by the beach. The annual maximum for 2009 was $0.19 \mathrm{gO}_{2} \mathrm{~m}^{2} \mathrm{~d}^{-1}$ in August. In 2010, the highest value was only $0.04 \mathrm{gO}_{2} \mathrm{~m}^{-2} \mathrm{~d}^{-1}$, but in June and July. In 2011, the highest values of $0.15 \mathrm{gO}_{2} \mathrm{~m}^{-2} \mathrm{~d}^{-1}$ were reported in April and December.

The share of the biotic oxygen consumption in the total oxygen consumption by the beach varies from a few per cent $(3.3 \%$ in January 2013, 4.7\% in October 2012) to a hundred per cent (January 2009, January-February 2010, January 2011). The average multi-annual (2009-2013) share of the biotic oxygen consumption in the total oxygen consumption by the beach is $52.3 \%$ (Fig. 2). The relation between the biotic oxygen consumption (in $\mathrm{gO}_{2} \mathrm{~m}^{-2} \mathrm{~d}^{-1}$ ) and its share, expressed as a percentage, in total oxygen consumption by the beach is statistically insignificant, the correlation coefficient of this relation is $r=0.1162$. Thus, based on measurements of total oxygen consumption, it is not possible to establish biotic oxygen consumption by the Vistula River beach.

\section{Discussion}

\subsection{Oxygen consumption in the beaches of the Vistula River and other European rivers}

The 1980s and 1990s of the 20th century saw the development of research on energy processes in lakes, estuaries and, to a smaller extent, rivers. Another aim of these stud- ies, although not openly admitted at the time, was to analyse the emission and binding of carbon dioxide by inland waters and their emission of methane - "greenhouse gases" affecting the Earth's thermal balance (Devol et al. 1988; Richey et al. 1988; Mann, and Wetzel 1995; Hamilton et al. 1995).

In literature, there is little data on oxygen consumption or, in general, on the energy flow through sandy sediments. Puczko (2013) states that, in most cases, these studies referred to small rivers and streams, less often to lowland rivers and rarely to large lowland rivers comparable to the Vistula River. Moreover, the researchers were interested rather in muddy and organic sediments than in "clean sand" which is considered to be biologically inactive, although it has been more than half a century since Wiszniewski's discovery of psammon. Therefore, to compare the results of oxygen consumption by the sandy beaches of the river such as the Vistula River obtained in this study with the data from literature is quite difficult. What is more, there are differences resulting from the applied measurement methods, a flow-through vessel method which gave results of an order of magnitude higher than the closed vessel method (Uzarski et al. 2004), while Bott (1978) states that the methods are comparable. Moreover, many of the results included in the literature cannot be compared with the data in this study due to the use of other units, e.g. G.-Toth (1992), G.-Toth et al. (1994), Simicic, and Mori (2007) do not use oxygen consumption per unit of sediment surface (bottom), but per unit of sediment weight.

Table 1 provides the results of the oxygen consumption in the sandy beaches of the Vistula River and data from the literature. Unfortunately, only in a few cases, the same methods of measurement were used - in these cases (Puczko 2013), very similar results were obtained (Table 1 ).

The oxygen consumption by the sandy beaches of the Vistula River (0.02$\left.0.55 \mathrm{gO}_{2} \mathrm{~m}^{-2} \mathrm{~d}^{-1}\right)$ can be compared with the oxygen consumption of the surface layer of 
Table 1. Oxygen consumption by riverine sediments (surface layer) and sandy sediments of the Baltic Sea. Source: Puczko (2013).

\begin{tabular}{|l|l|c|l|}
\hline $\begin{array}{l}\text { Oxygen consumption } \\
\left(\mathrm{gO}_{2} \mathrm{~m}^{-2} \mathrm{~d}^{-1}\right)\end{array}$ & $\begin{array}{l}\text { Name, type of river, } \\
\text { location, country }\end{array}$ & $\begin{array}{l}\text { Temp. } \\
\left({ }^{\circ} \mathrm{C}\right)\end{array}$ & Author \\
\hline $0.02-0.55$ & $\begin{array}{l}\text { Vistula River, a large, } \\
\text { lowland river, Poland }\end{array}$ & $0-30$ & This study \\
\hline $0.01-0.78$ & $\begin{array}{l}\text { Vistula River, a large, } \\
\text { lowland river, Poland }\end{array}$ & $0-27$ & Puczko 2013 \\
\hline 0.78 & $\begin{array}{l}\text { Steinen, a mountain } \\
\text { stream, Germany }\end{array}$ & 7.8 & Pusch, and Schwoerbel 1994 \\
\hline 1.7 & $\begin{array}{l}\text { Steinen, a mountain, } \\
\text { stream, Germany }\end{array}$ & $1-16$ & Pusch 1996 \\
\hline $4.6-7.0$ & $\begin{array}{l}\text { Neckar, in a mountain } \\
\text { course, Germany }\end{array}$ & $4-23$ & Urban-Malinga, and Opaliński 2002 \\
\hline $0.69-2.09$ & Gdańsk Bay, Baltic Sea & & \\
\hline
\end{tabular}

Table 2. The percentage share of abiotic oxygen consumption in total oxygen consumption by the river and the Baltic Sea beaches.

\begin{tabular}{|c|c|c|}
\hline $\begin{array}{c}\text { The share of abiotic oxygen } \\
\text { consumption in total } \\
\text { oxygen consumption (\%) }\end{array}$ & Location & Author \\
\hline 47.7 & Vistula River & This study \\
\hline $50-67$ & Vistula River, wet beach & Puczko 2013 \\
\hline $40-62$ & Vistula River, dry beach & Puczko 2013 \\
\hline $43-86$ & Baltic Sea, Gdańsk Bay, wet beach & Urban-Malinga, and Opaliński 1999 \\
\hline $10-50$ & Baltic Sea, Gdańsk Bay, dry beach & Urban-Malinga, and Opaliński 1999 \\
\hline
\end{tabular}

sediments of other rivers presented in the literature: the Steinen mountain stream in The Black Forest in Germany $\left(0.78-1.7 \mathrm{gO}_{2}\right.$ $\mathrm{m}^{-2} \mathrm{~d}^{-1}$ Table 1$)$. On the other hand, the data for the mountain course of the Neckar is an order of magnitude higher (Table 1). One should note that all the data quoted refer not to sandy sediments but to sediments consisting organic layer, where the intensity of oxygen consumption processes is higher due to the amount of organic matter. In this case, water purification by microorganisms (microbenthos) is not possible, as they live on organic material and rather release detritus or dissolved organic matter than purify water from these elements. The oxygen consumption by the Vistula beach is similar to that of the Baltic Sea beaches (Table 1), where the same method of measurement was used.

\subsection{Biotic and abiotic oxygen consumption}

Oceanographers that conduct research on oxygen consumption by seabed sediments distinguished three categories of this consumption: total oxygen uptake (TOC), benthic community respiration (BOC) and COD (chemical oxygen demand) which constitutes the part of total consumption that can be calculated after the addition of formaldehyde to water samples (Smith 1978; see also Teal, and Kanwisher 1961; Dale 1978; Boyton et al. 1981). In the research on oxygen consumption by the beaches of the Baltic Sea, Urban-Maling and Opaliński (1999) changed this terminology into total, biotic and abiotic oxygen consumption due to the existence of another meaning for the term "chemical oxygen demand" used in research on sewage. 
Table 3. Consumption of organic matter by the Vistula River beaches.

\begin{tabular}{|l|l|l|l|}
\hline $\begin{array}{l}\text { Average annual biotic } \\
\text { oxygen consumption } \\
\text { per day } \\
\left(\mathrm{g} \mathrm{m}^{-2} \mathrm{~d}^{-1}\right)\end{array}$ & $\begin{array}{l}\text { Equivalent of organic } \\
\text { matter of oxygen } \\
\text { consumption } \\
\left(\mathrm{g} \mathrm{Ww} \mathrm{g} \mathrm{O} \mathrm{F}_{2}^{-1}\right)\end{array}$ & $\begin{array}{l}\text { Average annual } \\
\text { organic matter } \\
\text { consumption per day } \\
\left(\mathrm{g} \mathrm{Ww} \mathrm{m} \mathrm{m}^{-2} \mathrm{~d}^{-1}\right)\end{array}$ & $\begin{array}{l}\text { Average annual organic } \\
\text { matter consumption } \\
\left(\mathrm{g} \mathrm{Ww} \mathrm{m}^{-2} \mathrm{y}^{-1}\right)\end{array}$ \\
\hline 0.083 & 9.37 & 0.78 & 284 \\
\hline
\end{tabular}

Another type of abiotic oxygen consumption is the photochemical processes occurring in water, but they do not play a significant role in the total oxygen consumption (Lindell, and Hakumant 1994). In this study, the aforementioned processes were eliminated by putting flasks, in which oxygen consumption was measured, in the dark place.

In the Vistula River beach, the abiotic oxygen consumption varied from $47.7 \%$ of the total oxygen consumption up to $100 \%$ in several months. There is insufficient data on abiotic oxygen consumption by sediments, Puczko (2013) states that the abiotic oxygen consumption by the Vistula beach constitutes of $40-67 \%$ of the total oxygen consumption. The values obtained in the results of this study coincide with the one of Puczko (2013) but are higher than the values concerning the Baltic Sea beaches (Table 2).

\subsection{Goods and services of the Vistula River sandy beaches}

Oxygen consumption by the Vistula River beaches is simply the respiratory processes of psammon living in these beaches. The oxygen consumed in the respiratory process is used to oxidize the organic matter eaten by psammon. Thus, based on the amount of oxygen consumed by the Vistula River beaches, one can calculate how much organic matter, in this case, the organic fraction of pollutants carried by the Vistula River (mainly communal sewage), was eaten and converted into carbon dioxide and water as a result of cellular combustion. Kajak (1998) states that the consumption of 1 g of oxygen in respiratory processes corresponds to the oxidation of $0.937 \mathrm{~g}$ of dry organic matter and $9.37 \mathrm{~g}$ of wet organic matter. So, $1 \mathrm{~m}^{2}$ of the Vistula beach between 2009-2013 consumed on average $0.78 \mathrm{~g}$ of wet organic matter per day, which gives an annual result of over a quarter of a kilogram (284 g) of organic matter (Table 3 ).

The Vistula beach La Playa, where the study was conducted, is about $250 \mathrm{~m}$ long and $5 \mathrm{~m}$ wide, so its area can be estimated at $1250 \mathrm{~m}^{2}$. On this basis, it can be calculated that this beach removes from the riverine water more than $1 / 3$ tonne of organic matter per year $\left(1250 \mathrm{~m}^{2}\right.$ time $284 \mathrm{~g} \mathrm{Ww}$ per $\mathrm{m}^{2}$ per 365 days $=355 \mathrm{~kg}$ ). To remove $1 \mathrm{~kg}$ of organic matter from communal sewage in a BIOSET type sewage treatment plant, $2.2 \mathrm{kWh}$ of electrical energy is required (Mysliński 2011). $1 \mathrm{kWh}$ of electricity costs PLN 0.354 (RWE Polska, G11 schedule for 2013), i.e. for the disposal of $1 \mathrm{~kg}$ of organic matter one should pay PLN 0.78. So, La Playa beach performs a "service" of disposal of $355 \mathrm{~kg}$ of organic matter per year, which is worth PLN 277. These PLN 277 per year are "goods and services of the ecosystem" (understood as in Constanza 1999; Constanza et al. 1997; Czech2002; Węsławski et al. 2006), so a tangible value of this stretch of a beach of the Vistula River in the middle of the city, and only "ecological" value, meaning a natural sewage treatment plant for the Vistula River, as one could still calculate its value as a place of recreation and rest (Węsławski et al. 2006; Andruszkiewicz, and Szeligiewicz 2011).

Therefore, La Playa beach is $250 \mathrm{~m}$ long and $5 \mathrm{~m}$ wide, free, no waste, "sewage treatment plant" of the Vistula River. For this natural treatment plant to operate, it is necessary to protect the beaches and sandbanks which means that no regulatory measures should be taken on the river. The regulation will cause water quality in the river to deteriorate. To preserve the current state of the Vistula waters, it would be necessary to build additional sewage treatment plants, which involves significant additional costs. 


\section{Bibliography}

Andruszkiewicz, Agata, and Wojciech Szeligiewicz. 2011. "Rozwój sportu i rekreacji nad Wisłą w Warszawie." Turystyka i Rekreacja 7: 77-82.

Bott, Thomas L., J. T. Brock, Colbert E. Cushing, S.V. Gregory, D. King, and R. C. Petersen. 1978. "A comparison of methods for measuring primary production and community respiration in streams." Hydrobiologia 60: 3-12.

Boyton, Walter R., W. Michael Kemp, C. G. Osborne, K. R. Kaumeyer, and M. C. Jenkins. 1981. "Influence of water circulation rate on in situ measurements of benthic community respiration." Marine Biology 65: 185-190.

Czech, Brian. 2002. "The imperative of macroeconomics for ecologists." BioScience 52: 964-966.

Constanza, Robert. 1999. "The ecological, economic and social importance of the oceans." Ecological Economics 31: 17-22.

Constanza, Robert, Ralph d'Arge, Rudolf de Groot, Stephen Faber, Monica Grasso, Burce Hannon, Karin Limburg, Shahid Naeem, Robert V. O’Neil, Jose Paruelo, Robert G. Raskin, Paul Sutton, and Marjan van den Belt. 1997. "The value of world's ecosystem services and natural capital." Nature 387(6630): 253-260.

Dale, T. 1978. "Total, chemical and biological oxygen consumption of the sediments in Lindaspollene, Western Norway." Marine Biology 49: 333-341.

Devol Allan H., Jeffrey E. Richey, Wayne A. Clark, Stagg L. King, and Luiz A. Martinelli. 1988. "Methane emission to the troposphere from the Amazon floodplain." Journal of Geophysical Research 93: 1583-1592.

G.-Toth, Laszlo. 1992. "Respiratory electron transport system activity (ETS) - activity of the plankton and sediment in Lake Balaton (Hungary)." Hydrobiologia 243/244: 157-166. G.-Toth, Laszlo, Zs. Lango, Judit Padisak, and E. Varga. 1994. "Terminal electron transport system (ETS) - activity in the sediment of Lake Balaton, Hungary." Hydrobiologia 281: 129-139.

Hamilton, Stephen K., Suzanne J. Sippel, and John M. Melack. 1995. "Oxygen depletion and carbon dioxide and methane production in waters of the Pantalan wetland of Brazil." Biogeochemistry 30: 114-141.
Kajak, Zdzisław. 1998. Hydrobiologia-Limnologia. Ekosystemy wód śródlądowych. Warszawa: Wydawnictwo Naukowe PWN.

Kleiber, Max. 1961. The fire of life. An introduction to animal energetics. New York - London: John Wiley.

Klekowski, Romuald Z., and Ann Duncan. 1975. "Physiological approach to ecological energetics." In Methods for ecological bioenergetics. Physiological approach to ecological energetics, edited by Władysław Grodziński, Romuald Z. Klekowski, and Ann Duncan, 15-64. Oxford: Blackwell.

Klekowski, Romuald Z., i Krzysztof W. Opaliński. 1993. „Metabolizm energetyczny." W Bioenergetyka ekologiczna zwierzat zmiennocieplnych, red. Romuald Z. Klekowski, Zofia Fisher, 3582. Warszawa: Polska Akademia Nauk.

Kozieł, Anna. 2013. Przeptyw energii przez ekosystem Wisty. Zużycie tlenu przez plaże suchą. Praca magisterska UKSW.

Lampert, Winfried. 1984. "The measurement of respiration." In A manual on methods for the assessment of secondary productivity in fresh water, edited by John A. Downing, and Frank H. Rigler, 413-469. Oxford: Blackwell Scientific Publications.

Lindell Mans J., and Rai Hakumat. 1994. "Photochemical oxygen consumption in humic waters." Archiv für Hydrobiologie 43: 145-155.

Ludwiniak, Marlena. 2013. Przeptyw energii przez ekosystem Wisty. Zużycie tlenu przez plaże mokra. Praca magisterska UKSW.

Mann, Caroll J., and Robert G. Wetzel. 1995. "Dissolved organic carbon and its utilization in a riverine wetland ecosystem." Biogeochemistry 31: 99-120.

Myśliński, Adam. 2011. Instrukcja ćwiczeń. UW Wydział Chemii, 24 czerwca, 2011. http://www.chem.uw.edu.pl/people/Mysliński/cw13/in13/htm.

Naegeli, Marcus W., and Urs Uehlinger. 1997. "Contribution of the hyporheic zone to ecosystem metabolism in a prealpine gravel bed river." Journal of the North American Benthological Society 16: 794-804.

Puczko, Magdalena. 2013. Przeptyw energii przez piaszczyste tawice i plaże Wisty oraz ich potencjalna rola $w$ rozktadzie materii organicznej. Praca doktorska PAN Centrum Badań Ekologicznych w Dziekanowie Leśnym. 
Pusch, Martin, and Juergen Schwoerbel. 1994. "Community respiration in hyporheic sediments of a mountain stream (Steina, Black Forest)." Archiv für Hydrobiologie 130: 35-52.

Push, Martin. 1996. "The metabolism of organic matter in the hyporheic zone of mountain stream, and its spatial distribution." $\mathrm{Hy}$ drobiologia 323: 107-118.

Richey, Jeffrey E., Allan H. Devol, Steven C. Wofsy, Reynaldo Victoria, and Maria N. G. Riberio. 1988. "Biogenic gases and the oxidation and reduction of carbon in Amazon River and floodplain waters." Limnology and Oceanography 33: 551-561.

Simicic, Tatjana., and Nataša Mori. 2007. "Intensity of mineralization in the hyporeic zone of the prealpine river Baca (West Slovenia)." Hydrobiologia 586: 221-234.

Smith, Kristi L. Jr. 1978. "Benthic community respiration in the N. W. Atlantic Ocean: in situ measurements from 40 to $5200 \mathrm{~m}$." Marine Biology 47: 337-347.

Teal, John M., and John Kanwisher. 1961. "Gas exchange in Georgia salt marsh." Limnology and Oceanography 6: 388-399.
Urban-Malinga, Barbara, and Krzysztof W. Opaliński. 1999. "Vertical zonation of the total, biotic and abiotic oxygen consumption on a Baltic sandy beach." Oceanological Studies 28: 85-96.

Urban-Malinga, Barbara, and Krzysztof W. Opaliński. 2002. "Seasonal changes of interstitial community respiration in a Baltic sandy beach." Oceanological Studies 31: 57-70.

Uzarski, Donald G., Craig A. Stricker, Thomas M. Burton, Donna K. King, and Alan D. Steinman. 2004. "The importance of hyporheic sediment respiration in several mid-order Michigan rivers: comparison between methods in estimation of lotic metabolism." $\mathrm{Hy}$ drobiologia 518: 47-57.

Węsławski, Jan Marcin, Eugieniusz Andrulewicz, Lech Kotwicki, Emil Kuzebski, Andrzej Lewandowski et al. 2006. „Basis for a valuation of the Polish Exclusive Economic Zone of the Baltic Sea: rationale and quest for tools." Oceanologia 48: 145-16.

Wiszniewski, Jerzy. 1934. "Recherches ecologiques sur le psammon et specialment sur les rotifers psammoniques." Archiwum Hydrobiologii i Rybactwa 8: 149-272. 